\title{
ORGANIZED CRIME AS A DYNAMIC AND COMPLEX CHALLENGE FACED BY THE MODERN SOCIETY
}

UDC 343.9.02

Nermin Halilagić ${ }^{1}$

$343.3 / .7$

State Investigation and Protecton Agency, Ministry of Security of Bosnia and Herzegovina

Received: 15.05 .2011

Accepted: 04.07.2011

\begin{abstract}
Organized crime is a complex and in many ways specific criminal phenomenon, now considered to be the most dangerous form of crime. It appeared relatively recently in both Bosnia and Herzegovina and the other republics of the former Yugoslavia. This work reviews the level of danger organized crime has presented to society through history. The author of the paper also refers to the characteristics of organized crime and highlights the presence of different both international and domestic opinions on the definition of the concept of organized crime, and the fact that today there is still no universal definition of the content of this concept. Also mentioned are criminal offenses related to organized crime.
\end{abstract}

Key words: organized crime, criminal acts, elements of organized crime.

\section{INTRODUCTION}

The expansion of organized crime is increasingly more present and it leads to new forms of manifestation, where the brashness, cunningness, professionalism, perseverance and the inhumanity of its perpetrators are becoming more and more alarming for the entire society. Organized crime in Bosnia and Herzegovina represents a recent phenomenon, since it essentially did not exist in the so-called Tito's Yugoslavia, which lasted until the beginning of the nineties of the last century. In the former state, the former Yugoslavia, one could only recognize individual rudimentary forms of organized crime, such as drugs trafficking, that were far behind the ones existing today in both their scope and the level of organization.

Other forms of organized crime (money laundering, human trafficking, illegal arms sales, smuggling of fuel and human organs) did not exist at all, or almost not at all. (Grubač, 2009).

1 Correspodence to:

Nermin Halilagić, MSc, State Investigation and Protecton Agency, Ministry of Security of Bosnia and Herzegovina

Nikole Tesle bb, 71123 Istočno Sarajevo

E-mail: halilagic_n@yahoo.com. 
Unfortunately, the situation in Bosnia and Herzegovina as well as all the republics of former Yugoslavia today paints a completely different picture that, in some instances, even has a disturbing character.

This is best seen in the case of murder of the Prime Minister of the first democratic government of Serbia, Dr Zoran Djindjic, that took place on 12 March 2003. Prime Minister was assassinated just as he announced the war against organized crime.

The reason for such expansion of organized crime can be found in the fact that it is a consequence of economic and political changes taking place in this region during the nineties of the last century, under dramatic circumstances. The transition processes were additionaly overburdened by the war.

The issue of organized crime has lately been very present in Bosnia and Herzegovina as well as in the world and, as such, it does not really leave the public indifferent. Wealth, secrecy and power of the members of criminal organizations, as well as the dangers that come along with organized crime, contribute to creating a special, one might even say a mystical picture of it. Organized crime offers to many relatively a lot of money (easy money), but what attracts people to this phenomenon, besides the money, are perhaps some other important goods, such as the status (of being "somebody")2. Organized crime exists as a phenomenon "everyone knows everything about" while, in reality, there are few of those who truly understand its functioning and structure (Ignjatovic, 1998). Many films and books on this subject, sensationalistic media reporting, and actual ignorance of most people regarding the topic contribute towards that and create a special picture of this complex criminal phenomenon. Generally, an image that the world

2 Supporting the foregoing paragraph is a statement by the Sicilian gangster Mannoia: "Many are convinced that people join the Cosa Nostra for the money. This is partly true. Are you really interested in why I did it? Because, before that, I was a Mr. Zero in Palermo. When I became a member of the mafia, everything was different: wherever I went, the heads bowed. And, for me, that was invaluable. "- stated in Paoli 1998: 280, (Petrović, Peršek 2007). is full of organized crime is created precisely because of the poor knowledge that exists on the topic. The term "organized crime" was used for the first time in history in time of Jonathan Wild (England, the beginning of the eighteenth century) and a gang of thieves that he was the leader of. Specifically, that term was used to describe the criminal activity they engaged in. Criminal gangs existed before, but this one showed certain specificities in its act.

The gang stole things to have them "found" later by the leader (Wild), who returned them to owners for a large prize. In case the owners did not want to buy the stolen items back, he sold them, in both England and around Europe.

Criminal activities of the Wild's gang, carried out as business, with connections established outside of their own country and under the protection of the then king, started being referred to as "organized crime" (Ignjatovic, 1998). Ever since then the society has been trying to identify appropriate mechanisms to adequately oppose this phenomenon.

Development of society brought with it the change in forms and shapes of manifestations of criminal activity.

In its historical efforts, the society has evidently tried different strategies to identify adequate responses to organized crime. Strategic approach provides for preventive and repressive activities of the state bodies in fighting organized crime, where the use of appropriate economic, legal and other measures contributes to a more effective engagement. In the seventies of the last century that engagement became particularly evident when organized crime, due to growing awareness of the actual level of danger it presented to the modern society, became the central theme of many national and international conferences, as well as scientific and expert gatherings. 
The fight against organized crime in the seventies of the twentieth century was mostly focused on the structure of criminal organizations, because the fight against organized crime that was taking place in the sixties, especially in America, focusing on the lower structures of criminal organizations, gave no satisfactory results. In the mid eighties of the twentieth century, the fight against organized crime was re-focused to the direct confiscation of assets derived from criminal activity. That prevented the use of illegally obtained profits in legal financial flows (Krivokapić, Bejatović and Banović, 2005). Organized crime is becoming more present in the field of general and economic crime, where it manifests itself in a very arrogant manner. The most common manifestations of organized crime in the field of general crime are related to serious property crimes: theft, robbery, aggravated robbery, vehicle theft, fraud and extortion.

Criminal acts of organized crime must be fully clarified and prove all the elements that classify it within the domain of organized crime, what simultaneously outlines requirements for effective preventive and repressive activities of the criminal justice system. To achieve this, it is necessary to be familiar with the conditions that contribute to the emergence and development of organized crime.

Therefore, it is very important to detect all the criminogenic factors causing the creation and development of all forms of organized criminal activity.

"That danger, incomparably greater than the dangers caused by the most severe acts of classic crime ${ }^{3}$ comes primarily from the fact that this type of crime is not easily recognized, detected and proved, because it is, as a rule, disguised as a regular activity, typically commercial, which, in addition, is also well organized and connect-

3 A Council of Europe document from 12 December 2003, titled "Safe Europe in a better light", lists organized crime as one of the major threats. ed with the relevant factors (individual or group ones), of political, civil, economic and social powers" (Grubač, 2009).

\section{MAIN CHARACTERISTICS OF ORGA- NIZED CRIME}

Although the term "organized crime" was first officially used in the report of the US Senate Committee, under the chairmanship of Senator E. Kafanner back in 1951, it is still very difficult to put together its comprehensive and unified conceptual definition (Singer, 1998). Justification for such situation may be partially found in the fact that, generally, there are still no reliable indicators to transparently specify the scope, manifestations, etiology and all the possible consequences, or the immediate threat of organized crime in a certain area. Today, when defining organized crime, it has become customary to define some of its characteristics on the basis of which presence or absence of organized crime is then established. Defining the basic characteristics of organized crime through identification of its concept is the first step in building an efficient strategy for its suppression. It is precisely these features that differentiate organized from conventional crime. Some of the mentioned features are (Petrović and Peršek, 2007):

- secrecy of the organization and its functioning (a factor without which the functioning of professional criminal organizations is unthinkable);

- permanent links between large number of individuals;

- hierarchical organizational structure, subordination and superiority;

- flexible, adaptable dealing in illegal activities, which are, therefore, always adjusted to the population demand; 
- planned execution of actions based on the division of labor (nothing is left to chance, everything is planned down to the smallest detail, in order to increase likelyhood of success);

- emergence of new types of crime (money laundering, forgery of credit cards, racketeering, pedophile porn industry, trade in human organs ...);

- share of profit (criminal organizations have an established organizational scheme, where everyone knows exactly who does what);

- use of various forms of intimidation, such as threats, extortion, forced protection, terror (in achieving their goals, gangsters and mafia members do not choose the means);

- increase in recidivism (a necessity due to the mass executions of criminal acts).

These criteria can be divided into two groups (Krivokapić, Bejatović and Banović, 2005):

- mandatory (criminal association ofthree or more persons, gaining financial benefit),

- optional (division of roles in the organization, use of various forms of intimidation).

Those are, in short, the main characteristics that we observe in all the known definitions of organized crime. Based on this, we can conclude that organized crime is easier to describe than to define. Previously listed characteristics of organized crime make it difficult to oppose this phenomenon, both from the aspect of prevention and repression (Krivokapić, Bejatović and Banović, 2005). Understanding the characteristics defining the operations of organized crime is much more important than the formal definition.
Based on those characteristics, we can determine the extent of measures that we will use to combat organized crime.

So, although there is no precise definition of organized crime, its main characteristics are known. Based on those characteristtics we can conclude that organized crime is a phenomenon that consists of execution of crimes by organized criminal associations or criminal organizations during the course of years, so that all the criminal acts committed within such framework of criminal association (criminal organization) represent the acts of organized crime. Criminal organization is an association of more than one per$\mathrm{son}^{4}$. Organized crime is often referred to as an anologous bureaucratic structure, similar to organizations of the army or the police, with strict hierarchy, discipline, responsibility, loyalty, and the division of tasks, based on its own norms, standards of behavior and understanding of values. All this together enables such criminal organizations to successfully execute criminal activities.

Audacity, cunningness, professionalism and perseverance are the side elements in the operation of organized crime.

By its organization, a criminal group may be interconnected in a looser or tighter way, and may be of temporary or permanent nature. Criminal organizations may take the shape of a group or a gang, and may be formed ad hoc in order to carry out one or more criminal offenses. Hierarchical nature of a criminal organization means that, with orders, the direct executor receives them from his immediate superior, who gets the orders from his senior leader, etc., all the way up to the leader of the organization.

Organizers or leaders of criminal organizations in most cases do not participate directly in the execution of crimes. Their role is to protect the group from detection and sanctioning.

4 According to the BiH Criminal Code Art. 1 Par. 17, criminal organization is an association of at least three persons. 
The main characteristic of such system of command and execution of both criminal and legal activities, is to make the eventual criminal responsibility of the hierarchically senior members, especially the leaders, very difficult to establish, and the evidence of the required level of proven credibility, that would clearly link such persons with criminal offenses committed by lower ranking members of the organization, very difficult to obtain (Škulić, 2004). Activities of the members of the organization, executions of criminal acts, are conducted on a professional basis.

The logical consequence of the objectives of criminal organizations, which are essentially of a criminal nature, is their secret character. This secrecy can be absolute or relative. Absolute secrecy is virtually impossible, because there is always a certain circle of people who know of the existence and operations of the organization. Relative secrecy is more common and it boils down to the ignorance of the police authorities regarding the existence and operations of such groups.

\section{CRIMINAL ACTS RELATED TO ORGANI- ZED CRIME}

Analysis of criminal acts may be done in different ways and based on different criteria. Criminal offenses committed by members of organized crime associations fall under the acts of organized crime, but only if the execution of a criminal act is a direct outcome of the objectives which were the purpose of the establishment of the criminal organization, and the reason it exists. Those offenses may be of different types, that, depending on the purpose of the execution of an offense and the goals that the criminal organizations or some of their members aim for, in relation to the execution of a particular crime, can be divided into five groups:

- crimes directly related to obtaining illegal profits (obtaining illicit financial gain) - for example, variety of property crimes (larceny, etc.);
- crimes important for the continued survival of the organization, or prevention of detection and proving of the crimes committed by members of the organization;

- crimes that facilitate expansion of the field of activities of a criminal organization, suppressing competition, etc;

- other crimes, associated with activities of the organization and its goals; for example, when a current or former member of criminal organization is sanctioned for any violation in respect of the rules that apply to members of a criminal organization - that person may, for example, become a passive subject of a murder or a serious bodily injury;

- crimes individually committed by the members of criminal organizations, out of their own reasons, independant from their involvement with the organization and not directly related with the activity of organization, nor committed to achieve or promote its goals. Those acts cannot be considered the crimes in the sphere of organized crime, but they can be very significant and can lead to related action of the criminal organization itself (Škulić, 2004).

\section{CONCLUSION}

From a historical point of view, organized crime has represented a new phenomenon observed in this region, but very quickly it caught up and even surpassed its competitors.

The region of former Yugoslavia was exposed to variety of organized crime activities, where the war troubles and the slowness in building of democracy in this area contributed to strengthening of the criminal groups and their development. 
That is why the fight against organized crime is a very important obligation of every country, including the countries in the region. In this sense, fight against organized crime deserves special attention and investment of efforts in all the segments, starting with the normative sphere, through the special bodies and procedures aimed at combating this social evil embodied in organized crime.

\section{REFERENCES}

Grubač, M. (2009). Organizovani kriminal u Srbiji. Zbornik radova Pravnog fakulteta u Splitu, god. 46, 4/2009., str. 701.-709.

Ignjatović, Đ.M. (1998). Organizovani kriminalitet. Beograd: Policijska akademija.

Krivokapić, V., Bejatović, S., \& Banović. B. (2005). Organizovani kriminalitet stanje i mjere zaštite (Organized crime - state and measures of protection), Zbornik radova. Beograd: Policijska akademija.

Petrović, B. \& Peršek, N. (2007). Sigurnost i suradnja kao reakcija na organizirani kriminalitet u srednjoj i jugoistočnoj Europi (Security and cooperation as response to organized crime in Central and Southeast Europe). zbornik radova, Pravni fakultet Univerziteta u Sarajevu.

Singer, M. (1998). Organizirani kriminal. Hrvatski ljetopis za kazneno pravo i praksu, 5, 2, 547-576.

Škulić, M. (2003) Organizovani kriminalitet - pojam $i$ krivičnoprocesni aspekti. Beograd: Dosije 